\title{
Fungicidal and micronutrients invigoration of groundnut for disease control and yield improvement in Pothowar, Pakistan
}

Tahir Amir Khan ${ }^{1 *}$, Abdul Hanan ${ }^{1}$, Muhammad Irfan², Zammurad Iqbal Ahmed $^{2}$, Waqas Ahmad ${ }^{3}$, Muhammad Zia-ul-Hassan ${ }^{4}$, Zulfiqar Ali Rahujo ${ }^{5}$, Abdullah Baloch ${ }^{1}$ and Muhammad Yaqub $^{6}$

1. Balochistan Agricultural Research and Development Centre, Quetta-Pakistan

2. Department of Agronomy, Faculty of Crops and Food Sciences, PMAS-Arid Agriculture University, RawalpindiPakistan

3. National Agricultural Research Centre, Islamabad-Pakistan

4. Adaptive Research Farm, Bhoon, Chakwaal-Pakistan

5. Agricultural Research Institute, Jaffarabad-Pakistan

6. Horticultural Research Institute, Khuzdar-Pakistan

*Corresponding author's email: info.maliktahir@gmail.com

\section{Citation}

Tahir Amir Khan, Abdul Hanan, Muhammad Irfan, Zammurad Iqbal Ahmed, Waqas Ahmad, Muhammad Zia-ulHassan, Zulfiqar Ali Rahujo, Abdullah Baloch and Muhammad Yaqub. Fungicidal and micronutrients invigoration of groundnut for disease control and yield improvement in Pothowar, Pakistan. Pure and Applied Biology. Vol. 6, Issue 4, pp1096-1102. http://dx.doi.org/10.19045/bspab.2017.600117

\begin{tabular}{llll}
\hline \hline Received: 12/04/2017 & Revised: 20/08/2017 & Accepted: 06/09/2017 & Online First: 09/09/2017 \\
\hline \hline
\end{tabular}

\section{Abstract}

Seed treatment with fungicides and micronutrients provides an opportunity to control various seed borne diseases and boosts the yield of many crops in a cost effective and better way as compared to the foliar application. Thus, an experiment was conducted to explore the effects of fungicidal and micronutrients seed treatment on groundnut crop at the Research Farm of PMAS-Arid Agriculture University, Rawalpindi (Pothowar Pleatue) Punjab, Pakistan during the kharif season 2016. Groundnut variety BARI2011 was subjected to 12 different treatments i.e. control, zinc (1\% solution in distilled water), boron ( $0.1 \%$ solution in distilled water), Radomil gold @ $2.5 \mathrm{~g}$, Topsim-M @ $2.5 \mathrm{~g}$, Puslaan @ $3 \mathrm{~g}$ (all in 1 litre of distilled water), and the combinations of both micronutrients with 3 fungicides at same concentrations. A randomized complete block design (RCBD) with 2 factors factorial arrangement having 3 replications was implemented in the field. Results indicated that seed treatment with the combination of $1 \%$ zinc and Radomil gold @ $2.5 \mathrm{~g} /$ litre solution in water resulted in the maximum plant height $(45.89 \mathrm{~cm})$, number of pods per plant (50 Nos.), 100 kernel weight $(64.39 \mathrm{~g})$, kernel weight $(1908 \mathrm{~kg} / \mathrm{ha})$, pod yield $(2778$ $\mathrm{kg} / \mathrm{ha}$ ), biological yield $(4590 \mathrm{~kg} / \mathrm{ha})$, harvest index $(41.56 \%)$, shelling percentage $(68.69 \%)$. Moreover, the crop was least infected by the seed borne diseases (3.27\%). These results suggest that seed treatment with the combination of $1 \%$ zinc and $2.5 \mathrm{~g} /$ litre of Radomil gold had effectively controlled the seed borne diseases as well as boosted the yield of groundnut by improving the yield components.

Keywords: Zinc; Radomil gold; Disease percentage; Yield components 


\section{Introduction}

Groundnut (Arachis hypogaea L.) is an oilseed crop of leguminoseae family grown in tropical and subtropical regions of the world due to its high oil $(50 \%)$ and protein (25\%) contents [1]. China, the United States and Argentina are the major groundnut producing countries in the world whereas Pakistan occupies $7^{\text {th }}$ position. In Pakistan, it is cultivated mainly in rain-fed and irrigated areas of Punjab and KPK, respectively. About $85 \%$ of total area under groundnut cultivation in Punjab lies in the Pothowar tract, producing $71 \%$ of the country's total production [2].

In 2012-13, the average yield of groundnut in Pakistan was $995 \mathrm{~kg} / \mathrm{ha}$ which is far less than the potential yield i.e., $4000 \mathrm{~kg} / \mathrm{ha}$. As groundnut is grown on sandy to sandy loam soils which are generally deficient in available nutrients, the average yield remains very low (about $75 \%$ less than the potential yield) [3]. Beside macronutrients, Pakistani soils are deficient in micronutrients, especially in zinc, iron, boron and copper which are the key factors in such low yield of groundnut [3].

Micronutrients are essential for satisfactory crop growth and production and the deficiencies of micronutrients can limit the metabolic and physiological processes even if the plants need only a small amount of micronutrients [4]. Zinc plays a vital role in the germination and crop growth $[5,6]$. It can improve the stand establishment, crop emergence and subsequent growth and yield. Moreover, higher seed zinc contents improve the resistance against soil-borne pathogens during germination and seedling development which result in good crop stands and ultimately better yield [7]. Beside zinc, boron application promotes the absorption of nitrogen by the groundnut crop and increases the plant height, the total number of pods and plant dry weight [8].
Another reason which drastically decreases the yield of groundnut is the spread of some diseases in the groundnut crop especially seed borne diseases. Many fungicides are reported to be useful against the seed borne diseases like collar rot disease of groundnut [9].

In crop plants, seed invigoration is a broader term and has been used in 2 different ways, i.e., seed priming and foliar application [10]. Seed priming with micronutrients improves the germination speed, minimizes the time between sowing and emergence, enhances seedling emergence and vigor, crop establishment and uplift yield [11-14]. Moreover, seed dressing with fungicides can be a handy technique for healthy seedling emergence by controlling seed borne diseases [15].

In the light of the importance of micronutrients and seed dressing with fungicides, the main objectives of the present study were:

To improve the health of seed by providing essential micronutrients for good crop stand establishment and yield of groundnut.

To control the disease with the help of seed treatment with micronutrients and fungicides.

To identify the best fungicide for the control of seed borne diseases.

\section{Materials and methods}

Groundnut variety BARI-2011 was sown in April, 2016 to investigate the effects of seed priming with 3 fungicides (Radomil Gold, Topsim-M and Puslaan) and 2 micronutrients (Zinc and Boron) at Research farm of PMAS-Arid Agriculture University, Rawalpindi, Pakistan. The farm is situated in the Pothowar pleatue which is considered as a rain-fed area. The rainfall in this area is more than $800 \mathrm{~mm} / \mathrm{annum}$, so a plenty of rainfall water is available for the crop. The soil of the farm is loamy type with a slightly alkaline nature. The seeds were collected from Barani Agricultural Research Institute, 
Chakwal, Pakistan. Four ploughings followed by planking were done for the preparation of fine seed bed. Sowing was done in rows using hand drill at the depth of 2.5 to $3 \mathrm{~cm}$. Row to row distance@ $45 \mathrm{~cm}$ and plant to plant distance @ $10 \mathrm{~cm}$ were kept for the groundnut crop. RCBD design with 2 factors factorial arrangement (Fungicides and Micronutrients) was laid out for 12 treatments with 3 replications. The total field area was 14 marlas which was divided into 3 blocks each containing 12 plots of size $2.70 \mathrm{~m} \times 2.70 \mathrm{~m}$. Three fungicides, viz. [Radomil gold @ 2.5 g/litre of water, Topsim-M @ 2.5 g/litre of water and Puslaan @ 3 g/litre of water] 2 Micronutrients, viz. [1\% solution of zinc and $0.1 \%$ solution of boron in distilled water] and combination of these levels of micronutrients with same levels of all 3 fungicides were applied to groundnut seeds before sowing. One plot in each block was left untreated as a control for comparison. All the solutions were prepared in 11 beakers and the seeds were soaked in these solutions for 10 hours during night and sowing was done in the next day early morning. Fertilizers (NPK) were applied @ 20,80 and $100 \mathrm{~kg} / \mathrm{ha}$ respectively, at the time of sowing. The crop was dependent only on the rainfall during the whole growing period. All other cultural practices were followed according to the standard recommendations.

The studied parameters were number of plants $\left(\mathrm{m}^{-2}\right)$, plant height $(\mathrm{cm})$, number of pods per plant, 100 kernel weight (g), kernel weight ( $\mathrm{kg} / \mathrm{ha})$, pod yield $(\mathrm{kg} / \mathrm{ha})$, biological yield ( $\mathrm{kg} / \mathrm{ha})$, harvest index $(\%)$, shelling percentage and percent disease. The harvest index, shelling percentage and percent disease were calculated using the following formula:

Harvest Index $=$ Grain yield $\times 100$

Biological yield

Shelling percentage $=\underline{\text { Kernel weight }} \times 100$
Pod weight

Percent disease $=$ Number of infected plants $\times 100$ Total number of plants

\section{Statistical analysis}

The mean values recorded for various parameters were subjected to analysis of variance technique as suggested by Steel \& Torrie [16]. Means were further separated using Tukey's honest significant difference (HSD) at the 95\% confidence level using Statistics 8.1 software.

\section{Results}

The number of plants $\left(\mathrm{m}^{-2}\right)$ counted at maturity was non-significant for all the treatments and their combinations. The plant height was significantly affected by the seed treatment with various fungicides and micronutrients (Table 1). The maximum plant height $(39.69 \mathrm{~cm})$ was observed in zinc treated seeds followed by the seeds treated with boron. The control resulted in the minimum plant height $(24.11 \mathrm{~cm})$ among all treatments.

The combinations of zinc and boron solutions with all the 3 fungicides depicted significant results for plant height as compared to the control (Table 2 and 3 ). The combination of zinc with Radomil gold resulted in the highest plant height (45.89 $\mathrm{cm}$ ) followed by the combination of zinc with Topsim-M and Puslaan. Similar trend was also noticed in the combination of boron with all the 3 fungicides.

The results of seed treatment with fungicides, micronutrients and their combinations for yield and yield contributing parameters were significant as compared to the control (Table 1, 2 and 3).

The seeds treated with zinc produced more number of pods per plant (45.33) and 100 kernel weight $(54.35 \mathrm{~g})$ followed by boron and Radomil gold. The control resulted in the minimum number of pods per plant (30.33) and 100 kernel weight (38.24 g) (Table 1).

The maximum number of pods per plant (50 nos.) and 100 kernel weight (64.39 g) 
produced by the combination of zinc and Radomil gold among all the treatments and their combinations (Table 1, 2 and 3). Furthermore, similar trends were noticed in the combination of boron with all the 3 fungicides for number of pods per plant and 100 kernel weight.

The yield parameters i.e., kernel weight, pod yield and biological yield were significantly higher in zinc treated seeds as compared to the control (Table 1). The seed treatment with zinc produced the higher kernel weight (1658 kg/ha), pod yield $(2590 \mathrm{~kg} / \mathrm{ha})$ and biological yield (4303 kg/ha) followed by boron and Radomil gold treated seeds.

The combination of zinc with Radomil gold produced the highest kernel weight (1908 $\mathrm{kg} / \mathrm{ha})$, pod yield (2778 $\mathrm{kg} / \mathrm{ha})$ and biological yield (4590 kg/ha) among all the treatments and their combinations (Table 1, 2 and 3). The combination of zinc and Puslaan produced the $2^{\text {nd }}$ highest results for the kernel weight, pod yield and biological yield. The control depicted the lowest values for kernel weight, pod yield and biological yield among all the treatments. Moreover, all the 3 yield parameters were significantly higher for the seeds treated with combination of boron and radomil gold as compared to the control (Table 3).

The maximum results for the harvest index $(41.56 \%)$ and shelling percentage $(68.69 \%)$ were obtained for the seeds treated with combination of zinc and Radomil gold followed by the combination of zinc and Puslaan (Table 1, 2 and 3). The lowest values of harvest index $(29.71 \%)$ and shelling percentage $(54.30 \%)$ were noted in the control.

The seed treatment with fungicides, micronutrients and their combination produced the significant results for percent disease (Table 1, 2 and 3). The percent disease was lowest $(3.27 \%)$ in the plots where seeds were treated with the combination of zinc and Radomil gold preceded by the plots in which the seeds were treated with the combination of zinc and Puslaan. The controlled plots showed the maximum values of percent disease among all the treatments.

Table 1. Effects of seed treatment with fungicides and micronutirents on the various studied parameters

\begin{tabular}{|l|l|l|l|l|l|l|l|l|l|l|}
\hline Treatments & $\begin{array}{l}\text { NOP } \\
\left(\mathbf{m}^{2}\right)\end{array}$ & $\begin{array}{l}\mathbf{P H} \\
(\mathbf{c m})\end{array}$ & NOPP & $\begin{array}{l}\text { KW } \\
(\mathbf{k g} / \mathbf{h a})\end{array}$ & $\begin{array}{l}\mathbf{1 0 0} \\
\mathbf{K W}(\mathbf{g})\end{array}$ & $\begin{array}{l}\text { PY } \\
(\mathbf{k g} / \mathbf{h a})\end{array}$ & $\begin{array}{l}\text { BY } \\
(\mathbf{k g} / \mathbf{h a})\end{array}$ & $\begin{array}{l}\mathbf{H I} \\
(\boldsymbol{\%})\end{array}$ & $\begin{array}{l}\mathbf{S P} \\
(\boldsymbol{\%})\end{array}$ & $\begin{array}{l}\text { PD } \\
(\boldsymbol{\%})\end{array}$ \\
\hline Control & 42.75 & 24.11 & 30.33 & 968 & 38.24 & 1782 & 3256 & 29.71 & 54.30 & 21.21 \\
\hline $\begin{array}{l}\text { Radomil gold (2.5 } \\
\text { g/litre) }\end{array}$ & 50.69 & 29.70 & 36.67 & 1306 & 43.28 & 2190 & 3692 & 35.37 & 59.60 & 10.94 \\
\hline $\begin{array}{l}\text { Topsim-M (2.5 } \\
\text { g/litre) }\end{array}$ & 47.67 & 25.71 & 32.33 & 1112 & 40.81 & 1986 & 3402 & 32.66 & 56.09 & 14.44 \\
\hline Puslaan (3 g/litre) & 48.67 & 27.60 & 35 & 1214 & 42.04 & 2096 & 3502 & 34.67 & 57.97 & 12.31 \\
\hline Zinc (1\% solution) & 50.97 & 39.69 & 45.33 & 1658 & 54.35 & 2590 & 4303 & 38.55 & 64.03 & 8.08 \\
\hline $\begin{array}{l}\text { Boron (0.1\% } \\
\text { solution) }\end{array}$ & 46.01 & 31.71 & 38 & 1380 & 44.91 & 2294 & 3762 & 36.69 & 60.17 & 13.05 \\
\hline CV (\%) & N.S & 1.80 & 4.31 & 116.55 & 2.48 & 139.54 & 122.9 & 3.47 & 3.84 & 6.08 \\
\hline
\end{tabular}

$\mathrm{NOP}=$ Number of plants, $\mathrm{PH}=$ Plant Height, $\mathrm{NOPP}=$ Number of pods per plant, KW= Kernel Weight, $100 \mathrm{KW}=$ 100 kernel Weight, PY= Pod Yield, BY= Biological Yield, HI= Harvest Index, SP= Shelling percentage, PD= Percent disease 
Table 2. Interaction effects of seed treatment with the combination of zinc and 3 fungicides on various studied parameters

\begin{tabular}{|l|l|l|l|l|l|l|l|l|l|l|}
\hline Treatment & $\begin{array}{l}\text { NOP } \\
\left(\mathbf{m}^{2}\right)\end{array}$ & $\begin{array}{l}\text { PH } \\
(\mathbf{c m})\end{array}$ & NOPP & $\begin{array}{l}\text { KW } \\
(\mathbf{k g} / \mathbf{h a})\end{array}$ & $\begin{array}{l}\mathbf{1 0 0} \\
\mathbf{K W}(\mathbf{g})\end{array}$ & $\begin{array}{l}\mathbf{P Y} \\
(\mathbf{k g} / \mathbf{h a})\end{array}$ & $\begin{array}{l}\mathbf{B Y} \\
(\mathbf{k g} / \mathbf{h a})\end{array}$ & $\begin{array}{l}\text { HI } \\
(\mathbf{\%})\end{array}$ & $\begin{array}{l}\text { SP } \\
(\%)\end{array}$ & $\begin{array}{l}\text { PD } \\
(\%)\end{array}$ \\
\hline Control & 42.75 & 24.11 & 30.33 & 968 & 38.24 & 1782 & 3256 & 29.71 & 54.30 & 21.21 \\
\hline $\begin{array}{l}\text { 1\% Zinc x 2.5 g/litre } \\
\text { Radomil gold }\end{array}$ & 51 & 45.89 & 50 & 1908 & 64.39 & 2778 & 4590 & 41.56 & 68.69 & 3.27 \\
\hline $\begin{array}{l}\text { 1\% Zinc x 2.5 g/litre } \\
\text { Topsim-M }\end{array}$ & 46.5 & 41.71 & 47 & 1728 & 57.33 & 2654 & 4358 & 39.66 & 65.10 & 5.93 \\
\hline $\begin{array}{l}\text { 1\% Zinc x 3 g/litre } \\
\text { Puslaan }\end{array}$ & 48 & 43.71 & 45 & 1800 & 61.14 & 2686 & 4452 & 40.44 & 67.02 & 4.16 \\
\hline CV (\%) & N.S & 2.05 & 5.71 & 124.48 & 4.96 & 108.28 & 73.62 & 3.25 & 3.47 & 5.94 \\
\hline
\end{tabular}

$\mathrm{NOP}=$ Number of plants, $\mathrm{PH}=$ Plant Height, NOPP= Number of pods per plant, KW= Kernel Weight, $100 \mathrm{KW}=100$ kernel Weight, PY= Pod Yield, BY= Biological Yield, HI= Harvest Index, SP= Shelling percentage, PD= Percent disease

Table 3. Interaction effects of seed treatment with the combination of boron and 3 fungicides on various studied parameters

\begin{tabular}{|l|l|l|l|l|l|l|l|l|l|l|}
\hline Treatment & $\begin{array}{l}\text { NOP } \\
\left(\mathbf{m}^{2}\right)\end{array}$ & $\begin{array}{l}\mathbf{P H} \\
(\mathbf{c m})\end{array}$ & NOPP & $\begin{array}{l}\text { KW } \\
(\mathbf{k g} / \mathbf{h a})\end{array}$ & $\begin{array}{l}\mathbf{1 0 0} \\
\mathbf{K W}(\mathbf{g})\end{array}$ & $\begin{array}{l}\mathbf{P Y} \\
(\mathbf{k g} / \mathbf{h a})\end{array}$ & $\begin{array}{l}\text { BY } \\
(\mathbf{k g} / \mathbf{h a})\end{array}$ & $\begin{array}{l}\text { HI } \\
(\mathbf{\%})\end{array}$ & $\begin{array}{l}\text { SP } \\
(\boldsymbol{\%})\end{array}$ & $\begin{array}{l}\text { PD } \\
(\mathbf{\%})\end{array}$ \\
\hline Control & 42.75 & 24.11 & 30.33 & 968 & 38.24 & 1782 & 3256 & 29.71 & 54.30 & 21.21 \\
\hline $\begin{array}{l}0.1 \% \text { Boron x 2.5 } \\
\text { g/litre Radomil } \\
\text { gold }\end{array}$ & 48.55 & 37.81 & 44.67 & 1586 & 52.18 & 2528 & 4168 & 38.04 & 62.74 & 9.18 \\
\hline $\begin{array}{l}\text { 0.1\% Boron x 2.5 } \\
\text { g/litre Topsim-M }\end{array}$ & 44.45 & 33.70 & 42.33 & 1454 & 48.04 & 2348 & 3932 & 37.01 & 61.98 & 10.01 \\
\hline $\begin{array}{l}\text { 0.1\%Boron x 3 } \\
\text { g/litre Puslaan }\end{array}$ & 46.80 & 35.67 & 41.67 & 1514 & 50.68 & 2442 & 4072 & 37.19 & 62.01 & 10.23 \\
\hline CV (\%) & N.S & 2.08 & 7.58 & 134.36 & 2.87 & 143.2 & 54.24 & 3.61 & 4.22 & 6.22 \\
\hline
\end{tabular}

$\mathrm{NOP}=$ Number of plants, $\mathrm{PH}=$ Plant Height, NOPP= Number of pods per plant, KW= Kernel Weight, $100 \mathrm{KW}=100$ kernel Weight, PY= Pod Yield, BY= Biological Yield, HI= Harvest Index, SP= Shelling percentage, PD= Percent disease

\section{Discussion}

Seed treatment triggers cellular, sub-cellular and molecular changes in seeds and increases seed vigour during germination and emergence that results in the good stand establishment and finally better yield of the crop [17, 18]. In the present study, seed treatment with fungicides, micronutrients and their combinations restricted the disease infestation considerably and enhanced the plant height, yield and yield contributing parameters. This suggests that seed treatment is an important technique for boosting the overall yield of groundnut. Increase in plant height of groundnut may be attributed to zinc because it improves crop emergence, stand establishment and subsequent growth of the crop [5, 6]. Kernels of the treated plots with the combination of zinc and Radomil gold were healthier with vigorous growth and larger in size which resulted in the increase of 100 kernel weight, kernel yield and shelling percentage, whereas, kernels of control plots were smaller due to the stunted growth of plants. These results are in line with Sekhar and Sekaran [19] who reported that the application of various fungicides show positive results in controlling seed borne diseases and increase $57 \%$ dry pod yield, considerably enhance 100 kernel weight and shelling percentage. Similarly, Marschner 
[7] reported that higher seed zinc contents improve the resistance against soil-borne pathogens during germination and seedling development resulting in good crop stands with healthy kernels.

In our study, the highest pod and biological yield of groundnut was noted in the plots treated with zinc and Radomil gold combination. This may be attributed to the increased number of pods per plant of groundnut due to the seed priming with zinc and Radomil gold. However, the increase in pod yield of groundnut may be attributed to Radomil gold which is useful fungicide in controlling seed borne diseases and helps in the better growth of crop with healthy pods thereby increasing dry pod yield [19]. The improvement in the biological yield of groundnut may be attributed to seed priming with zinc which is responsible for the better crop emergence, seedling vigor, yield and biomass of the crop [20].

Seed treatment with the combination of zinc and Radomil gold also showed the better harvest index and shelling percentage as compared to the control. The highest harvest index and shelling percentage with zinc and Radomil gold seed treatment might be due to more economic yield, i.e., healthy kernels with no empty pod. Ali and Seyyed [21] reported the results which are very close to our findings that micronutrients seed treatment produced the higher number of fertile flowers, mature pods, 100-seed weight and shelling percentage resulting in the increased pod yield and ultimately high harvest index (\%) of groundnut crop.

The present study also showed the minimum disease percentage in seed treatment with zinc and Radomil gold combination. This may be due to both zinc and Radomil gold as reported by Marschner [7] that higher seed zinc contents improve the resistance against soil-borne pathogens which results in good crop stands with healthy kernels. Deeb et al. [22] also reported that treating groundnut seeds with fungicides reduces the disease percentage of groundnut which ultimately results in the increased pod yield. Findings of this study suggest that seed treatment with the combination of $(1 \%)$ zinc solution and (2.5 g/litre of water) Radomil gold resulted in the better growth and yield of groundnut (variety BARI-2011). These research findings have an implication for enhancement of yield of groundnut which can be further implied on other leguminous crops. Finally, these findings will help motivate our farmer to adopt seed treatment technique to apply micronutrients and fungicides to tackle the diseases efficiently and to boost the yield.

\section{Authors' contributions}

Conceived and designed the experiments: TA Khan, M Irfan ZI Ahmed, Performed the Experiments: TA Khan, M Irfan, W Ahmad \& MZU Hassan, Analyzed the Data: TA Khan \& A Hanan, Contributed reagents/ materials/ analysis tools: ZA Rahujo, A Baloch \& M Yaqub, Wrote the paper: TA Khan.

\section{References}

1. Amjad M (2014). Oilseed crops of Pakistan. Status paper. Plant Sci. Div. Pakistan Agric Res Council Islamabad pp. 1-40.

2. Government of Pakistan (2012). Crops area and production (by districts) 201112. Agriculture and Livestock, Ministry of Food, Islamabad 116-117.

3. Imtiaz M, Rashid A, Khan P, Memon MY \& Aslam M (2010). The role of micronutrients in crop production and human health. Pak J Bot 42(4): 25652578.

4. Nasiri Y, Zehtab-Salmasi S, Nasrullah zadeh S, Najafi N \& Ghassemi-Golezani $\mathrm{K}$ (2010). Effects of foliar application of micronutrients ( $\mathrm{Fe}$ and $\mathrm{Zn}$ ) on flower yield and essential oil of chamomile (Matricaria chamomilla L.). J Med Plants Res 4(17): 1733-1737. 
5. Marwat KB, Arif M \& Khan MA (2007). Effect of tillage and $\mathrm{Zn}$ application methods on weeds and yield of maize. Pak J Bot 39(5): 1583-1591.

6. Nawab K, Ullah A, Arif M, Shah P, Rab A, Khan MA, Khan MA \& Khalid K (2011). Effect of FYM, potassium and zinc on phenology and grain yield of wheat in rainfed cropping systems. Pak $J$ Bot 43(5): 2391-2396.

7. Marschner H (1995). Mineral Nutrition of Higher Plants. 2nd Ed. Academic; London, pp. 889-895.

8. Jing RF, Zhang QG, Han LF, Zhang FS \& Wei XQ (1994). Effect of boric fertilizer on peanut absorption of boron and nitrogen. Soils 26: 83-86.

9. Gangopadhyay S, Bhatia JN \& Godara SL (1996). Evaluations of fungicides for the control of collar rot of groundnut. $J$ Mycol Plant Pathol 26(3): 278-279.

10. Farooq M, Basra SMA, Wahid A, Khaliq A \& Kobayashi N (2009). Rice seed invigoration. In: Lichtfouse E. editor. Sustainable Agriculture Reviews; Springer(Netherlands). pp. 137-175.

11. Ali S, Arif M, Gul R, Khan A, Shah SS \& Ali I (2007). Improving maize seed emergence and early seedling growth through water soaking. Sci Khyber 19: 173-177.

12. Arif M, Ali S, Shah A, Javed N \& Rashid A (2005). Seed priming maize for improving emergence and seedling growth. Sarhad J Agric 21: 539-543.

13. Deering, RH \& Young TP (2006). Germination speeds of exotic annual and native perennial grasses in California and the potential benefits of seed priming for grassland restoration. Proc. California Native Grasslands Assoc 16: 14-17.

14. Diniz KA, Silva PA, Oliveira JA \& Evangelista JRE (2009). Sweet pepper seed responses to inoculation with microorganisms and coating with micronutrients, amino acids and plant growth regulators. Sci Agric 66: 293297.

15. Karthikeyan A (1996). Effect of organic amendments antagonist Trichoderma viride and fungicides on seed and collar rot of groundnut. Plant Disease Res 11: 72-75.

16. Steel RGD \& Torrie JH (1984). Principles and procedures of statistics (2nd Ed.). MC Graw Hill Book Co Singhapore pp. 172-177.

17. Godfery WN, Onyango JC \& Beck E (2004). Sorghum and salinity: II. Gas exchange and chlorophyll fluorescence of sorghum under salt stress. Crop Sci 44: 806-811.

18. Mirshekari B (2012). Seed priming with iron and boron enhances germination and yield of dill (Anethum graveolens). Turk J Agric For 36: 27-33.

19. Sekhar MJ \& Sekaran RR (2008). Effect of fungicides on key diseases of groundnut in relation to crop stage. Trop Pest Manage 37(3): 270-272.

20. Ajouri A, Asgedom H \& Becker $M$ (2004). Seed priming enhances germination and seedling growth of barley under conditions of $\mathrm{P}$ and $\mathrm{Zn}$ deficiency. J Plant Nut and Soil Sci 167: 630-636.

21. Ali AG \& Seyyed ANN (2010). Effects of iron and nitrogen fertilizers on yield and yield components of peanut (Arachis hypogaea L.) in Astaneh Ashrafiyeh, Iran. American-Eurasian J Agric and Envir Sci 9(3): 256-262.

22. Deeb AA, Abdel-Momen SM \& Hanafi AA (2002). Effect of some fungicides and alternative compounds on root and pod rots in peanut. Egypt J Agric Res 80: 71-82. 